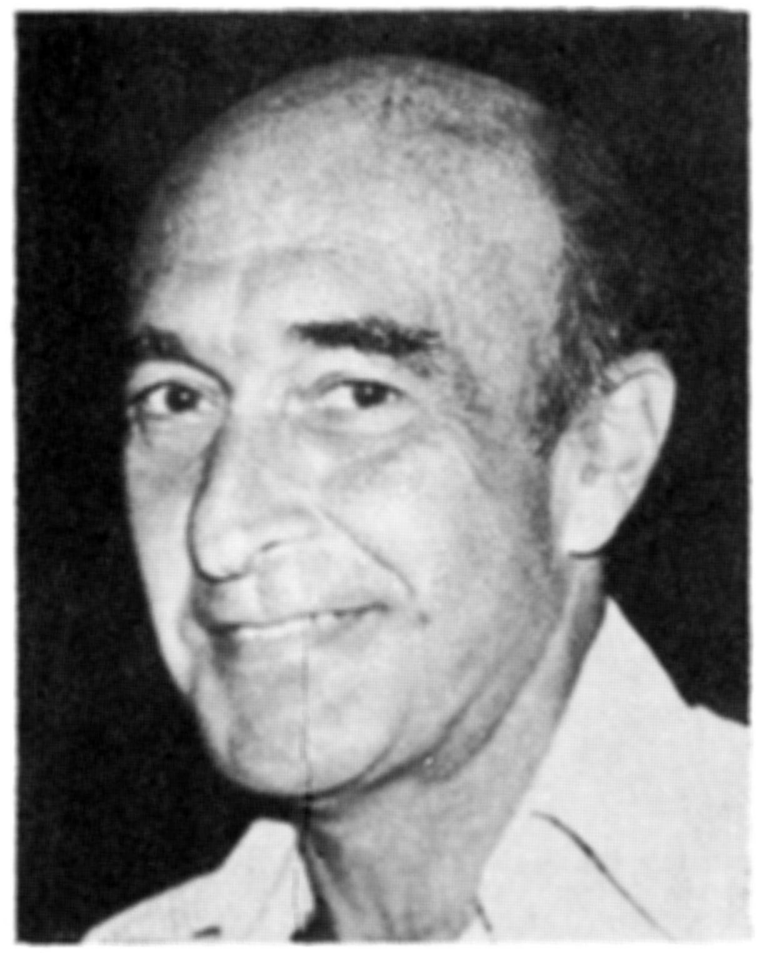

\title{
IN M EMORIA M
}

VIRGILIO GONCALVES PEREIRA

(1931 - 1984)

Aos 53 anos de idade, faleceu, em São Paulo, o Prof. Dr. Virgilio Goncalves Pereira, vulto de médico cuja memória ficará marcada nos anais da Medicina Brasileira. Intusiasmado pelas possibilidades da terapia intensiva, organizou e chefiou os departamentos da UTI em vários dos principais hospitais de São Paulo. No Hospital das Clínicas da Faculdade de Medicina da Universidade de São Paulo, criou a Unidade de Choque na qual, sob sua direção aprenđeram e se aperfeiçoaram jovens médicos, cujos conhecimentos foram levados a muitas regióes do País. A simples leitura de seu Memorial, já em 1978, quando se candidatara para o cargo de Professor Adjunto de Clínica Médica, revela sua criatividade e seu labor contínuo, constituindo ele uma honra para a Faculdade de Medicina da Universidade de São Paulo, em que sempre trabalhou. Graduado em 1954 pela Faculdade de Medicina da Universidade Federal da Bahia, transferiu-se imediatamente para São Paulo onde por diversos anos frequentou e trabalhou na Primeira Clínica Médica do Hospital das Clínicas (Serviço do Prof. Ulhôa Cintra). Nesse serviço, defendeu, em uma mesma linha de investigação, suas teses de Doutoramento e de Docência-livre. Incontáveis conferências e cursos foram por ele ministrados. Muitas foram as teses elaboradas sob sua orientação. Colaborou em capítulos sempre atualizados, em muitos livros didáticos. Seus trabalhos científicos, sempre com caráter de inovação e de aporte de novos dados, pontilharam a literatura médica nacional.

Embora não fosse neurologista, Virgilio Gonçalves Pereira colaborava continuamente com a maior parte de nossos especialistas. Incumbia-se da terapêutica de sustentação de seus casos, mantendo-os em condições metabólicas adequadas. Esses cuidados muito facilitavam a terapêutica das condições estritamente neurológicas, favorecendo a evolução desses pacientes e melhorando o prognóstico. Desse convívio, aliado a seus conhecimentos de metabologia, sua inteligência brilhante assimilou com facilidade as bases essenciais da patologia nervosa. Muitos trabalhos e registros de casos, em colaboração com colegas neurologistas, documentam seu interesse por nossa especialidade. 